\title{
FARMER PERCEPTION TO ISPO IN OIL PALM PLANTATION IN WEST JAVA
}

\author{
${ }^{1)}$ Ernah, ${ }^{1)}$ Apong Sandrawati, ${ }^{1)}$ Melania Fadillah, ${ }^{1)}$ Dewi Rengganis, ${ }^{1)}$ Sudarjat Sudarjat \\ ${ }^{1)}$ Faculty of Agriculture, Padjadjaran University Email:ernah@unpad.ac.id
}

\begin{abstract}
Palm oil is one of the leading commodities in the world market that contributes to the Indonesian economy. In fulfilling market demand but environmental friendly, the Indonesian government issued a policy of sustainable standards known as the Indonesian Sustainable Palm Oil (ISPO) principle. This study aims to determine the farmers' perception of ISPO in the community of oil palm farmers in West Java. This study designed as qualitative research. The results show that not all standards were sustainable. ISO has been applied to oil palm plantations in West Java. For this reason, government efforts were needed to assist farmers in implementing the ISPO.
\end{abstract}

Keywords: Farmers, Oil Palm, Sustainable, West Java, ISPO.

\section{INTRODUCTION}

Indonesia is of the largest palm oil producer in the world. Based on the status of the concession in 2015 , about 18 million tons of palm oil came from large private plantations. A 10 million tons from smallholder plantations and 2 million tons came from large state plantations (Indonesian Plantation Statistics, 2015).

West Java is one of the provinces in Indonesia which has the potential to develop the oil palm plantations. Table 1 shows the development of oil palm production and area in West Java, which increased from 2011 to 2014 in the area and production. In 2011 amounted to 9 hectares and 16 thousand tons of production. It increased in 2014 to 14 hectares and 33 tons.

Table 1. Area and Palm Oil Production in West Java in 2011 - 2014

\begin{tabular}{ccc}
\hline Year & Area $(\mathrm{Ha})$ & Production (Ton) \\
\hline 2011 & 9,196 & 16.793 \\
2012 & 9,039 & 20.072 \\
2013 & 13,611 & 32.643 \\
2014 & 14,077 & 33.518 \\
\hline
\end{tabular}

Source: Directorate General of Plantations 2015
Table 2 Area of Oil Palm Plantations in 2015.

\begin{tabular}{llc}
\hline No & Regency & Area $(\mathrm{Ha})$ \\
\hline 1 & Subang & 158 \\
2 & Garut & 80 \\
3 & Tasikmalaya & 15 \\
4 & Pangandaran & 6 \\
\hline
\end{tabular}

Source: Directorate General of Plantations 2015

Table 2 shows that Subang and Tasikmalaya Regencies are smallholder plantations in West Java that can already produce fresh fruit bunches (FFB). The largest oil palm plantation in Subang Regency with an area of $158 \mathrm{Ha}$.

Good economic prospects for palm oil commodity, examined from the increasing consumption and production of palm oil in the global market. It implicates the decrease of environmental quality and social inequality (Obidzinski, et al (2012); Rist, et al (2010)) Therefore, awareness is needed to manage palm oil production and consumption sustainably. This awareness led to initiatives from the Indonesian government to issue sustainable standards. In 2011 the Indonesian government issued a regulation regarding the Minister of Agriculture Number 19/Permentan/ OT.14/ 3/2011/March 29, 2011 concerning the 
Indonesian Sustainable Palm Oil Plantation Guidelines. It is called Indonesia Sustainable Palm Oil (ISPO). ISPO is a reference in developing sustainable oil palm plantations in Indonesia where in the ISPO guidelines there are various laws and regulations relating to the exploitation of oil palm plantations in Indonesia. (Imansari, 2015). This regulation was updated on March 2015 to become the Sustainable Palm Oil Certification System. Regulations regarding ISPO standards are mandatory for all plantation companies but voluntary for smallholder businesses (Ministry of Agriculture, 2015).

The ISPO standard consists of 7 principles as follows:

1. Plantation management and licensing system

2. Application of technical guidelines for palm oil processing culture

3. Environmental management and monitoring

4. Responsibility towards workers

5. Responsibility towards individuals and communities

6. Empowering community economic activities

7. Commitment to continuous economic improvement

In Government Regulation Number 11/Permentan/OT.140/3/2015, the ISPO principle consists of several attachments depending on the type of business, namely:

a. Appendix II for plantation companies that carry out integrated plantation cultivation business with processing and renewable energy

b. Appendix III for plantation companies that carry out plantation cultivation business

c. Appendix IV for companies engaged in the processing of plantation products

d. Appendix $\mathrm{V}$ for the plasma plantation business

e. Appendix VI for the independent garden business

One of the objectives of ISPO implementation is the achievement of environmentally friendly oil palm products (Agustina et al., 2014; Ernah, 2015; Fuadah and Ernah, 2018). Smallholder oil palm plantations contribute $40 \%$ of national production (Directorate General of Plantations, 2015).

Various problems faced by oil palm farmers in Indonesia, especially independent smallholders, include (1) farmers having a low bargaining value on the price of fresh fruit marks (FFB); (2) farmers often use seeds that are not qualified and organized, so it is difficult to get capital (Pramudya, et al, 2015). Farmers, especially independent smallholders who implement ISPO, are still few in Indonesia due to several reasons, including the lack of ISPO socialization to farmers (Astari and Lovett 2019; Higgins and Richards 2019)

\section{RESEARCH METHOD}

The object of this study was farmers who have and were still working independently on palm oil in Serang panjang Regency, Subang Regency, and Panca tengah District, Tasikmalaya Regency by using census method. This investigation was conducted from June to September 2017 using a qualitative approach. Qualitative research design intended to understand the phenomena about what was experienced by the research subjects such as behavior, perception, motivation, actions and so on holistically (intact) by describing data in the form of words, and language and utilizing various natural methods . Determination of location was done intentionally based on observations and secondary data. Data sources used in this study consisted of primary data and secondary data (Sachan et al. 2018; Chen and Rui 2018). Primary data obtained from surveys and in-depth interviews, while secondary data originated from literature.

\section{RESULTS AND DISCUSSION}

The local farmer oil palm plantations in Subang Regency were the 
largest in West Java, located in Serang panjang District with an area of approximately $115 \mathrm{Ha}$, which covers three villages, Cinta mekar, Talagasari, and Leles. The first land clearing was carried out in 2007, together with the formation of the Cinta mekar farmer group. Then in 2008, oil palm was planted using seeds from PTPN VIII and the Medan Palm Oil Research Center (PPKS).

Tasikmalaya Regency is one of the areas that develop oil palm plantations in West Java. The location is in the Panca tengah District, precisely in Neglasari Village with an area of $30 \mathrm{Ha}$, including 10 Ha for TM and $20 \mathrm{Ha}$ for TBM where oil palm cultivation in Neglasari Village began in 2008.

Characteristics of Oil Palm Farmers. The characteristics of oil palm growers include gender, age, level of education, length of farming, and farming status (Chin et al. 2019; Jelsma et al. 2019). The survey showed the majority of oil palm farmers are male, aged 41-50 years old, have planted oil palm for 12 years, and make this oil palm farming as the primary income (Table 3 ).

\section{Principles of Indonesia Sustainable} Palm Oil (ISPO). In this case, the ISPO principles that used were the legality of plantations, the organization of farmers and the management of farmers, the management, monitoring of the environment, and sustainable business improvement. The results of interviews with farmers illustrate the application of policies made by the government regarding guidelines for conducting sustainable palm oil plantation business. (Setiawan et al. 2016; Larsen et al. 2014)

Table 3. Characteristics of Oil Palm Farmers

\begin{tabular}{|c|c|c|}
\hline No & Characteristics & Number of people \\
\hline \multirow[t]{3}{*}{1} & Gender & \\
\hline & Male & 30 \\
\hline & Female & 4 \\
\hline \multirow[t]{5}{*}{2.} & Age (year) & \\
\hline & $30-40$ & 12 \\
\hline & $41-50$ & 13 \\
\hline & $51-60$ & 8 \\
\hline & $61-65$ & 1 \\
\hline \multirow[t]{5}{*}{3.} & Education & \\
\hline & Elementary & 24 \\
\hline & Junior high school & 4 \\
\hline & Senior high school & 5 \\
\hline & Bachelor & 1 \\
\hline \multirow[t]{7}{*}{4} & Long work (year) & \\
\hline & 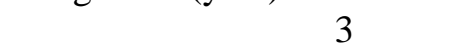 & 12 \\
\hline & 5 & 4 \\
\hline & 7 & 5 \\
\hline & 8 & 1 \\
\hline & 9 & 5 \\
\hline & 10 & 7 \\
\hline \multirow[t]{3}{*}{5} & Farming Status & \\
\hline & Main income & 21 \\
\hline & Side income & 13 \\
\hline Tota & & 34 \\
\hline
\end{tabular}

Source: Survey 2017 
Farmers' Perception of Indonesian Sustainable Palm Oil (ISPO). Perception is a process in organizing and interpreting the stimulus that will be received by organisms or individuals so that it can be meaningful as the most intimate activity in individuals (Walgito, 2004). If related to farmers' perceptions of ISPO, it can be interpreted that these perceptions were the views that farmers have in seeing the benefits derived from the ISPO principles as guidelines in their oil palm plantation business.

Four ISPO principles can be used for independent oil palm plantations, namely: the legality of independent smallholders the organization of smallholders and the management of independent smallholders, environmental management and monitoring, sustainable business improvement. Farmers' perceptions illustrate their views on policies made by the government regarding guidelines for sustainably conducting oil palm plantations.

Oil Palm Farmers' Perception on Plantation Legality. The existence of legality can provide a guarantee or protection for individuals to avoid problems (Jamaludin, Muis, and Hashim 2019; Afriyanti, Kroeze, and Saad 2016),. Based on surveys and interviews, the majority of oil palm farmers in West Java agreed with the legality of the plantation. This was due to the protected land ownership status of farmers. Based on the facts in the field, the oil palm farmers already have proof of land ownership, such as the deed of sale and purchase certificates and land. It aims to protect farmers legally, from problems caused by other parties that will be detrimental. In carrying out planting, farmers must know and pay attention to the existence of the location of the plantation under the determination of spatial planning, access to the location of the farm to transport most farmers have a good view of the legality of the gardens contained in this ISPO principle. Farmers realize that the legality of managing their plantations with best practices will be able to maintain and improve the quality of oil palm.

Oil Palm Farmers 'Perception on Farmers' Organization and Plantation Management. According to Robbins (2006), the organization is a forum formed by the community in achieving results that previously could not be achieved individually. This organization will relate to work and environmental situations so there will be many interrelated behaviors such as tasks, work, attendance, work shifts, productivity, human appearance and management that aim to achieve common goals.

The majority of farmers agreed with the organization of farmers and nursery management. With the existence of an organization or farmer group, it is easier for oil palm farmers to obtain information on care to market prices. Besides, with the management based on ISPO standards, farmers are expected to be able to do their farming business better.

The oil palm farmer said that in an agricultural activity an organization is needed, which can help farmers to improve their farming, such as the presence of an organization or farmer group of oil palm farmers will be easier to exchange and obtain information about care or prices in the market. Management of oil palm plantations can be done by maintaining the plantation and monitoring the condition of the plantation so that it can suppress pests and diseases that attack plants. Maintenance that can be done by farmers is to make terraces before planting on sloping land, making dishes and maintaining dishes can simplify the process of fertilizing and harvesting, planting ground cover crops (such as beans) can add nutrients in the soil while in order to reduce interference from pests and plant diseases, farmers can provide fertilizer or pesticides, besides farmers can weed or remove weeds. (Alwarritzi, Nanseki, and Chomei 2015; Santika et al. 2019)

Farmers' Perceptions of Environmental Management and Monitoring. Environmental 
management is an effort that is done consciously in maintaining or improving environmental quality, it aims to meet basic human needs in order to be fulfilled (Soemarwoto, 1989). Within the ISPO principles, there are provisions for oil palm growers or entrepreneurs to carry out environmental management and monitoring. This can be seen from the excellent response of farmers and based on survey data obtained in the field. (Jamaludin, Muis, and Hashim 2019; Papilo et al. 2018) Farmers are of the view that environmental management and monitoring can maintain and reduce negative impacts on the community and the surrounding environment. Management and monitoring of the environment, together with the farmers, can be done, for instance, by fire prevention in the plantation(Jimu and Nyakudya 2018; Keizer et al. 2018) . In addition, farmers also have to pay attention to the biodiversity conservation in oil palm plantation.

Farmers' Perceptions of Sustainable Business Improvement. Mostly, farmers agreed to the sustainable business improvement contained in ISPO where they have the view that with the evaluation or advice is given from various relevant agencies can improve and improve the performance of farmers. Also, the existence of farmer groups can help in increasing plantation business while affecting farmers' income.

The continuous increase in business is because farmers have the view that with the evaluation or advice given from various relevant agencies will be able to improve and improve the performance of farmers or farmer groups in improving their plantation business (Tan and Lim 2019; Pye 2019).

\section{Constraints faced by Oil Palm Farmers.} Independent palm oil farmers have several obstacles in conducting farming, such as the lack of a forum to obtain information and insights from farmers. This is due to the absence and non-operation of farmer groups, which makes it difficult for farmers to exchange information and assistance. Another obstacle is the lack of capital and assistance for capital loans, making it difficult for farmers to take good care. Also, the lack of socialization from the government and other relevant agencies, causes palm oil farmers are less aware of the ISPO standard as a guide in sustainably conducting oil palm farming.

\section{CONCLUSIONS AND SUGGESTIONS}

Based on the results of the discussion, it can be concluded that oil palm farmers in West Java can make ISPO as a reference in developing and managing sustainable community oil palm plantations. However, independent oil palm growers have several obstacles, particularly lack of information on the standards of sustainable oil palm plantations and lack of capital for farmers to take care and manage good farming.

For this reason, more serious attention is needed from the government to provide guidance or provide socialization regarding ISPO to oil palm farmers. It is also hoped that existing farmer groups will be activated more so that they can assist farmers in obtaining various information to improve the quality and quantity of oil palm

\section{ACKNOWLEDGMENT}

The authors thank the Chancellor of Padjadjaran University and UNPAD's DRPMI for the assistance of the 2017 Unpad Internal Grants (HIU) grant scheme. The authors also thank all those who have provided the information needed for this study. 


\section{BIBLIOGRAPHY}

Afriyanti, Dian, Carolien Kroeze, and Asmadi Saad. 2016. "Indonesia Palm Oil Production without Deforestation and Peat Conversion by 2050." Science of The Total Environment 557-558 (July): 562-70. https://doi.org/10.1016/j.scitotenv.2016.03.032.

Agustina, Dewi; Hariyadi dan Saharuddin. 2014. Analisis Lingkungan Sosial Ekonomi Pengelolaan Perkebunan Kelapa Sawit Berkelanjutan Berdasarkan Kriteria Ispo Pt. Tapian Nadenggan. Jurnal Pengelolaan Sumberdaya Alam dan Lingkungan Vol. 4 No. 1.

Alwarritzi, Widya, Teruaki Nanseki, and Yosuke Chomei. 2015. "Analysis of the Factors Influencing the Technical Efficiency among Oil Palm Smallholder Farmers in Indonesia." Procedia Environmental Sciences 28: 630-38. https://doi.org/10.1016/j.proenv.2015.07.074.

Astari, Annisa Joviani, and Jon C. Lovett. 2019. "Does the Rise of Transnational Governance 'hollow-Out' the State? Discourse Analysis of the Mandatory Indonesian Sustainable Palm Oil Policy.” World Development 117 (May): 1-12. https://doi.org/10.1016/j.worlddev.2018.12.012.

Chen, Shuangshuang, and Hongxing Rui. 2018. "A Node-Centered Finite Volume Method for a Fracture Model on Triangulations." Applied Mathematics and Computation 327 (June): 5569. https://doi.org/10.1016/j.amc.2018.01.024.

Chin, Hon-Choong, Weng-Wai Choong, Sharifah Rafidah Wan Alwi, and Abdul Hakim Mohammed. 2019. "A PLS-MGA Analysis of Farming Characteristics on the Intentions of Smallholder Oil Palm Planters to Collect Palm Residues for Biofuel Production." Biomass and Bioenergy 120 (January): 404-16. https://doi.org/10.1016/j.biombioe.2018.11.012.

Direktorat Jenderal Perkebunan. 2015. Statistik Perkebunan Indonesia Komoditas Kelapa Sawit 2014-2016. Jakarta.

Dinas Perkebunan Jawa Barat. 2015. Perkembangan Luas dan Produksi Perkebunan Kelapa Sawit Rakyat Provinsi Jawa barat Tahun 2010-2015. http://disbun.jabarprov.go.id/backend/assets/data/statistik/Kelapa_Sawit_Perkebunan_Rakyat_ 20151.pdf

Ernah. 2015. Cost-Benefit Analysis Of The Introduction Of The Indonesian Sustainable Palm Oil Standards: A Case Study In Jambi Province, Sumatra, Indonesia.EEPSEA Reports.

Fuadah, Deilla Tsamrotul dan Ernah. 2018. Pengelolaan Perkebunan Kelapa Sawit Berdasarkan Prinsip ISPO di PTPN VIII Cikasungka, Jawa Barat. Jurnal IlmuPertanian Indonesia (JIPI) Vol. 23 (3): 190-195.

Higgins, Vaughan, and Carol Richards. 2019. "Framing Sustainability: Alternative Standards Schemes for Sustainable Palm Oil and South-South Trade." Journal of Rural Studies 65 (January): 126-34. https://doi.org/10.1016/j.jrurstud.2018.11.001.

Imansari, SaqiraYunda. (2015).PenetapanKebijakan Indonesian Sustainable Palm Oil (ISPO) Pada Tahun 2011.e-Journal IlmuHubunganInternational.UNEJ.

Jamaludin, Nabila Farhana, Zarina Ab Muis, and Haslenda Hashim. 2019. "An Integrated Carbon Footprint Accounting and Sustainability Index for Palm Oil Mills." Journal of Cleaner Production 225 (July): 496-509. https://doi.org/10.1016/j.jclepro.2019.03.312. 
Jelsma, Idsert, Lotte S. Woittiez, Jean Ollivier, and Arya Hadi Dharmawan. 2019. "Do Wealthy Farmers Implement Better Agricultural Practices? An Assessment of Implementation of Good Agricultural Practices among Different Types of Independent Oil Palm Smallholders in Riau, Indonesia." Agricultural Systems 170 (March): 63-76. https://doi.org/10.1016/j.agsy.2018.11.004.

Jimu, Luke, and Innocent W. Nyakudya. 2018. "Fires in Exotic Forest Plantations of Zimbabwe: Causes and Management Strategies." World Development Perspectives 9 (March): 56-58.

Keizer, J.J., F.C. Silva, D.C.S. Vieira, O. González-Pelayo, I. Campos, A.M.D. Vieira, S. Valente, and S.A. Prats. 2018. "The Effectiveness of Two Contrasting Mulch Application Rates to Reduce Post-Fire Erosion in a Portuguese Eucalypt Plantation." CATENA 169 (October): 21-30. https://doi.org/10.1016/j.catena.2018.05.029.

Kementerian Pertanian. 2015. Sistem Sertifikasi Kelapa Sawit Berkelanjutan Indonesia (ISPO). Diambil dari http://perundangan.pertanian.go.id/admin/file/Permentan\%20112015\%20ISPO.pdf . [30 Agustus 2017]

Larsen, Rasmus Kløcker, Norman Jiwan, Arie Rompas, Johanes Jenito, Maria Osbeck, and Abetnego Tarigan. 2014. "Towards 'hybrid Accountability' in EU Biofuels Policy? Community Grievances and Competing Water Claims in the Central Kalimantan Oil Palm Sector." Geoforum 54 (July): 295-305. https://doi.org/10.1016/j.geoforum.2013.09.010.

Obidzinski, K., Andriani, R., Komarudin, K., \&Andrianto, A. (2012). Environmental and social impacts of oil palm plantations and their implications for biofuel production in Indonesia. Ecology and Society, 17(1). doi: 10.5751/es-04775-170125.

Papilo, Petir, Marimin, Erliza Hambali, and Imas S. Sitanggang. 2018. "Sustainability Index Assessment of Palm Oil-Based Bioenergy in Indonesia." Journal of Cleaner Production 196 (September): 808-20. https://doi.org/10.1016/j.jclepro.2018.06.072.

Pramudya, E. P., Prawoto, A., \&Hanifa, R. (2015). Menghijaukan Sektor Sawit Melalui Petani Lesson-Learned Hivos untuk Isu Sawit Berkelanjutan. Jakarta: Renebook.

Pye, Oliver. 2019. "Commodifying Sustainability: Development, Nature and Politics in the Palm Oil Industry.” World Development 121 (September): 218-28. https://doi.org/10.1016/j.worlddev.2018.02.014.

Rist, L., Feintrenie, L., \&Levang, P. (2010). The livelihood impacts of oil palm: smallholders in Indonesia. Biodiversity and Conservation,19(4), 1009-1024. doi: 10.1007/s10531-0109815-z.

Robbins, S. P., Judge, T. A. 2006. Perilaku Organisasi. Edisi Bahasa Indonesia. PT. Indeks Kelompok Gramedia. Jakarta.

Sachan, D.K., P. Kumar, P.N. Dwivedi, and A. Bhattacharya. 2018. "Accurate Estimation of Shell Position Using Triangulation Method for Calibration of RPS." IFAC-PapersOnLine 51 (1): 225-30. https://doi.org/10.1016/j.ifacol.2018.05.049.

Santika, Truly, Kerrie A. Wilson, Sugeng Budiharta, Elizabeth A. Law, Tun Min Poh, Marc Ancrenaz, Matthew J. Struebig, and Erik Meijaard. 2019. "Does Oil Palm Agriculture Help Alleviate Poverty? A Multidimensional Counterfactual Assessment of Oil Palm Development in Indonesia." World Development 120 (August): 105-17. https://doi.org/10.1016/j.worlddev.2019.04.012. 
Setiawan, Eko N., Ahmad Maryudi, Ris H. Purwanto, and Gabriel Lele. 2016. "Opposing Interests in the Legalization of Non-Procedural Forest Conversion to Oil Palm in Central Kalimantan, Indonesia." Land Use Policy 58 (December): 472-81. https://doi.org/10.1016/j.landusepol.2016.08.003.

Statistik Perkebunan Indonesia. 2015. Kelapa Sawit 2015-2017. DirektoratDjendral Perkebunan.

Soemarwoto, Otto. 1989. Ekologi Lingkungan Hidup dan Pembangunan. Djamatan. Jakarta

Sugiyono.2017. Metode Penelitian Kuantitatif Kualitatif dan R\&D. Penerbit Alfabeta. Bandung.

Tan, Yue Dian, and Jeng Shiun Lim. 2019. "Feasibility of Palm Oil Mill Effluent Elimination towards Sustainable Malaysian Palm Oil Industry." Renewable and Sustainable Energy Reviews 111 (September): 507-22. https://doi.org/10.1016/j.rser.2019.05.043

Walgito. 2004. Pengantar Psikologi Umum. Andi. Yogyakarta 